\title{
The Study of Deformation Behaviour of DC06 Deep Drawing Steel
}

\author{
Michal Tregler ${ }^{1}$, Pavel Kejzlar², Tomáš Pilvousek ${ }^{3}$, Zuzana Andršová², Lukáš Voleský² \\ ${ }^{1}$ Faculty of Mechatronics, Informatics and Interdisciplinary Studies, Technical University of Liberec, Studentska \\ 1402/2, 46117 Liberec, Czech Republic. Email: michal.tregler@tul.cz \\ ${ }^{2}$ Department of the Preparation and Analysis of Nanostructures; Institute for Nanomaterials, Advanced Technologies \\ and Innovation, Technical University of Liberec, Studentska 1402/2, 46117 Liberec, Czech Republic. Email: pavel.kej- \\ zlar@tul.cz, lukas.volesky@tul.cz,zuzana.andrsova@email.cz \\ ${ }^{3}$ Škoda Auto, VFS1, V. Klementa 869, 29360 Mladá Boleslav, Czech Republic. Email: tomas.pilvousek@skoda- \\ auto.cz
}

The occurrence of any cracks or defects in car body parts processed by deep drawing technology is not allowed by high quality standards. This kind of defect is considered as the most dangerous for the process quality and stability because it cannot be easily detected during the manufacturing in the steel plant and also in final inspection after pressing, that's why the occurrence of these defects has always to be studied in detail. For the prevention of defects, it is necessary to study the deformation behaviour of the material in the immediate vicinity the crack tip in detail. For the study the controlled scratched samples were tensile deformed and then were studied using UHR-SEM equipped witd EBSD detector. The EBSD technique allowed detailed inspection of the effect of deformation on the grain structure as changes in grain orientation or local crystal lattice missorientation and thus directly observe and evaluate both, elastic and plastic strain. Obtained results showed that the scratch does not affect deformability of the DC06 deep drawing sheet negatively due to too large tip radius with respect to low sheet thickness.

Keywords: EBSD, Deformation, Stress, Strain, Structure

\section{Acknowledgement}

Authors wish to thank to the institutional support of Technical University of Liberec, Faculty of Mechanical Engineering, Department of Materials and to the project LO1201 "Národní program udržitelnosti I" and to the Škoda Auto a.s. that participated on the presented research.

\section{References}

[1] ANDERSON, T. (2005). Fracture mechanics: fundamentals and applications. 3rd ed. Boca Raton, FL: Taylor \& Francis

[2] VELES, P. (1985). Mechanické vlastnosti a skúšanie kovov: celoštátna vysokoškolská učebnica pre hutnícke a strojnícke fakulty vysokých škôl. 1. vyd. Bratislava: Alfa

[3] BROBERG, K. B. (1999). Cracks and Fracture. London: Academic Press

[4] WRIGHT, S. I., NOWELL, M. M., FIELD, D. P. (2011). A Review of Strain Analysis Using Electron Backscatter Diffraction. In: Microscopy and Microanalysis, Vol. 17, No. 03, pp. 316-329

[5] Characterizing local strain variations around crack tips using EBSD mapping. Application note. Available online: http://www.oxford-instruments.com/getmedia/2cf71e40-9a0d-4f49-9113-69475a4c84fb/Characterising-localstrain-variations-around-crack-tips-using-EBSD-mapping

[6] BREWER, L. N. et al. (2002). Misorientation Mapping for Visualization of Plastic Strain via Electron Back-Scattered Diffraction. In: Microscopy and Microanalysis, Vol. 8, No. 02, pp. 684-685.

[7] WILKINSON, A. J., Britton, T. B. (2012). Strains, planes, and EBSD in materials science. In: Materials Today, Vol. 15, No. 9, pp. 366-376

[8] WILKINSON, A.J., DINGLEY, D.J. (1991). Quantitative deformation studies using electron back scatter patterns. In: Acta Metallurgica et Materialia, Vol. 39, No. 12, pp. 3047-3055

[9] KAMAYA, M. (2009). Measurement of local plastic strain distribution of stainless steel by electron backscatter diffraction. In: Materials Characterization, Vol. 60, No. 2, pp. 125-132

[10]KEJZLAR, P., ANDRŠOVÁ, Z., ŠVEC, M. (2015). Structure of Al-targets Used for PVD Coating in Jewellery. In: Manufacturing technology, Vol. 15, No. 4, pp. 553 - 557.

[11]KEJZLAR, P., PILVOUSEK, T. (2015). DC 06 ZE Deep Drawing Sheet Crack Analysis. Will be published in: Scientific.net 
[12]EN 10152 Electrolytically zinc coated cold rolled steel flat products for cold forming - Technical delivery conditions. Škoda Auto a.s. - internal factory documents.

[13]Kovové materiály - zkoušení tahem ČSN EN ISO 6892-1. (2010). Praha : Úřad pro technickou normalizaci, metrologii a státní zkušebnictví.

[14]LEJČEK, P., NOVÁK, P. (2008). Fyzika kovi̊. Praha. Available online: http://old.vscht.cz/met/stranky/vyuka/studijni_materialy/fyzika_kovu/fyzika_kovu.pdf

\section{Paper number: M201658}

Copyright $\odot$ 2016. Published by Manufacturing Technology. All rights reserved. 